\title{
PENGGUNAAN BERBAGAI MEDIA TANAM DAN INOKULASI SPORA UNTUK MENINGKATKAN KOLONISASI EKTOMIKORIZA DAN PERTUMBUHAN Shorea javanica
}

\section{THE APLICATION OF VARIOUS PLANTING MEDIA AND SPORE INOCULUMS TO IMPROVE ECTOMYCORRHIZAL COLONIZATION AND GROWTH OF Shorea javanica}

\author{
Oleh/By: \\ Wiwin Febriani, Melya Riniarti dan Surnayanti \\ Jurusan Kehutanan Fakultas Pertanian Universitas Lampung \\ Jl. Soemantri Brojonegoro No. 1 Bandar Lampung \\ Email: wiwinfebriani94@gmail.com ; wiwin.1214151065@ students.unila.ac.id \\ HP: +6285609665913
}

\begin{abstract}
ABSTRAK
Jenis media tanam merupakan salah satu faktor penentu dalam keberhasilan kolonisasi ektomikoriza dan pertumbuhan tanaman. Penelitian ini bertujuan untuk mendapatkan jenis media yang paling berpengaruh dalam meningkatkan kolonisasi ektomikoriza dan pertumbuhan Shorea javanica. Percobaan dilakukan di rumah kaca selama empat bulan. Rancangan percobaan menggunakan rancangan acak lengkap dengan empat perlakuan media tanam yang terdiri dari tanah, pasir, arang sekam dan cocopeat. Ektomikoriza yang digunakan diberikan dalam bentuk suspensi spora (Scleroderma columnare) sebanyak $20 \mathrm{ml}$ setiap tanaman. Data dianalisis dengan menggunakan uji Barlett untuk mengetahui homogenitas ragam yang dilanjutkan dengan analisis ragam dan BNT. Hasil penelitian menunjukkan bahwa media pasir memberikan hasil terbaik dibandingkan media lainnya dalam membentuk kolonisasi ektomikoriza; sedangkan media pasir dan tanah merupakan media terbaik untuk meningkatkan pertumbuhan $S$. javanica yang diinokulasi dengan $S$. columnare.
\end{abstract}

Kata Kunci: ektomikoriza, kolonisasi, media tanam, Shorea javanica

\begin{abstract}
Media is a decisive factor to succed the ectomycorrhizal colonization and plant growth. This study aimed to get the best planting media to increase ectomycorrhizal colonization and growth of Shorea javanica. The experiment was conducted in a greenhouse for four months. The experimental designed by randomized complete design with four treatments upon the planting media: soil, sand, husk and cocopeat. Ectomycorrhiza given as spore suspension (Scleroderma columnare) of $20 \mathrm{ml}$ each plant. Data were analyzed using the Bartlett test to determine homogeneity of variance followed by analysis of variance and LSD. The results shown that the sand provides the best results compared to another media to form ectomycorrhiza colonization; while sand and soil were the best media to support the growth of $S$. javanica with inoculation of S. Columnare.
\end{abstract}

Keyword : colonization, ectomycorrhiza, Shorea javanica, planting media 


\section{PENDAHULUAN}

Damar mata kucing (Shorea javanica) merupakan jenis pohon lokal yang ada di Repong Damar, Krui Pesisir Barat. Pohon ini adalah salah satu jenis pohon dari famili Dipterocarpaceae yang batangnya dapat mengeluarkan resin dan kayunya digunakan sebagai bahan bangunan. Hasil samping berupa resin ini menjadi salah satu keunggulan karena masyarakat tetap dapat mengambil hasil hutan yang bernilai jual tanpa menebang pohon. Menurut Purwaningsih (2004), populasi jenis Dipterocarpaceae di Indonesia saat ini sedang mengalami degradasi yang sangat cepat. Hal ini disebabkan proses pembalakan yang terjadi secara terus menerus dalam skala besar. Jika keadaan ini terus berlanjut maka akan banyak jenis dari famili Dipterocarpaceae yang hanya dapat dilihat pada gambar tanpa keberadaannya di hutan.

Menurut Mansur (2013), kesiapan bibit dari segi kualitas adalah salah satu faktor yang harus diperhatikan dalam mendukung kegiatan pembangunan hutan. Bibit yang akan digunakan dalam penanaman harus memenuhi beberapa persyaratan yaitu sehat, ukuran yang sesuai (tinggi 30-50cm), jumlah sesuai kebutuhan dan tersedia tepat waktu. Persyaratan tersebut akan terpenuhi jika perlakuan dan perawatan bibit diperhatikan sebaik mungkin.

Media tanam merupakan salah satu faktor yang memengaruhi kualitas bibit. Saat ini banyak alternatif media pengganti tanah yang telah dikenal dan digunakan masyarakat contohnya pasir, arang sekam padi dan cocopeat. Media tanam yang baik adalah media yang mampu menunjang pertumbuhan bibit, pertumbuhan mikroba dan pertumbuhan fungi yang berguna bagi perkembangan bibit.

Mikoriza merupakan salah satu fungi yang berguna untuk membantu pertumbuhan tanaman. Salah satu jenis mikoriza adalah ektomikoriza yang berasosiasi dengan akar tanaman tingkat tinggi. Ektomikoriza membantu akar tanaman untuk menyerap unsur hara dan air yang diperlukan dalam fotosintesis. Menurut Prameswari (2004), S. javanica dapat bersimbiosis dengan ektomikoriza jenis Scleroderma columnare.

Persen kolonisasi ektomikoriza pada akar tanaman tampaknya dipengaruhi oleh keadaan dan jenis media tanam yang digunakan. Oleh karena itu, perlu adanya suatu informasi ilmiah tentang jenis media tanam yang cocok untuk meningkatkan kolonisasi ektomikoriza sehingga dapat meningkatkan kualitas bibit yang nantinya akan digunakan dalam pembangunan hutan tanaman.

Penelitian ini bertujuan untuk mendapatkan jenis media yang paling berpengaruh dalam meningkatkan kolonisasi ektomikoriza pada damar mata kucing ( $S$. javanica), serta mempelajari pengaruh penggunaan berbagai jenis media tanam yang diinokulasi dengan $S$. columnare terhadap pertumbuhan damar mata kucing (S. javanica).

\section{METODE PENELITIAN}

Bibit dan media tanam yang digunakan dalam penelitian ini yaitu bibit damar mata kucing (S. javanica) berumur 4 bulan, media tanah, pasir, arang sekam dan cocopeat. Masing-masing media tersebut dimasukkan ke dalam polybag bening ukuran $15 \times 30 \mathrm{~cm}$ kemudian dilapisi dengan polybag warna hitam. Media tanam yang digunakan dalam penelitian ini tidak dilakukan sterilisasi terlebih dahulu.

Inokulum yang digunakan berbentuk suspensi spora yang berasal dari tubuh buah $S$. columnare. Suspensi spora dibuat dengan cara mencampurkan 5 gram spora ke dalam 1 liter aquades dan diberi empat tetes tween 80, lalu diaduk perlahan menggunakan magnetic stirerr hingga tercampur merata. Setiap bibit $S$. javanica diinokulasikan dengan $20 \mathrm{ml}$ suspensi spora dan diberikan di dekat perakaran tanaman. 
Penelitian dilaksanakan selama empat bulan di rumah kaca dengan pemeliharaan tanaman berupa penyiangan gulma dan penyiraman yang disesuaikan dengan kapasitas lapang masing-masing media tanam. Variabel pengamatan meliputi : tinggi bibit, diameter, jumlah daun, luas daun, berat kering akar, berat kering pucuk, berat kering total, panjang akar dan persen kolonisasi akar berektomikoriza.

Penghitungan variabel luas daun dilakukan dengan menggunakan alat leaf area meter. Jumlah akar berektomikoriza dihitung secara langsung di bawah mikroskop stereo dengan menggunakan metode the gridline intersection (Brundrett et al.1996). Persen kolonisasi akar berektomikoriza dihitung dengan menggunakan rumus sebagai berikut.

$$
\text { Persen akar terkolonisasi }=\frac{\text { Jumlah akar terkolonisasi ektomikoriza }}{\text { Jumlah seluruh akar yang diamati }} \times 100 \%
$$

Rancangan percobaan yang digunakan adalah Rancangan Acak Lengkap (RAL) dengan 4 perlakuan media tanam yang terdiri dari media tanah (P1), pasir (P2), arang sekam (P3) dan cocopeat (P4). Masing-masing perlakuan diulang sebanyak 3 kali dan menggunakan 5 sampel tanaman. Data hasil penelitian diuji dengan menggunakan uji Barlett untuk mengetahui homogenitas ragam. Setelah semua data homogen, maka dilanjutkan dengan analisis ragam untuk mengetahui adanya perlakuan yang memberikan pengaruh nyata terhadap variabel penelitian. Kemudian nilai tengah perlakuan diuji lanjut dengan menggunakan uji Beda Nyata Terkecil (BNT).

\section{HASIL DAN PEMBAHASAN}

\section{HASIL}

Rekapitulasi hasil analisis ragam (Tabel 1) diperoleh bahwa perlakuan jenis media tanam berpengaruh sangat nyata terhadap semua variabel penelitian. Perbedaan nilai tengah pada setiap perlakukan diketahui dengan melakukan uji lanjut Beda Nyata Terkecil (BNT) untuk seluruh variabel penelitian yang disajikan pada Tabel 2.

Tabel 1. Rekapitulasi analisis ragam untuk seluruh variabel penelitian penggunaan berbagai media tanam dan ektomikoriza untuk meningkatkan kolonisasi dan pertumbuhan damar mata kucing (S. Javanica)

\begin{tabular}{lccccccccc}
\hline Perlakuan & $\boldsymbol{\Delta T}$ & $\boldsymbol{\Delta D}$ & $\boldsymbol{\Sigma} \mathbf{D}$ & $\mathbf{L D}$ & $\mathbf{B K P}$ & $\mathbf{B K A}$ & $\mathbf{B K T}$ & $\mathbf{P A}$ & $\mathbf{K}$ \\
\hline $\begin{array}{l}\text { Jenis media } \\
\text { tanam }\end{array}$ & $* *$ & $* *$ & $* *$ & $* *$ & $* *$ & $* *$ & $* *$ & $* *$ & $* *$ \\
\hline
\end{tabular}

Keterangan:

** : berbeda nyata pada taraf nyata $1 \%$

$\mathrm{T}$ : pertambahan tinggi tanaman

$\mathrm{D}:$ pertambahan diameter tanaman

DD : jumlah daun

LD : luas permukaan daun

BKA : berat kering akar

BKT: berat kering total

PA : panjang akar

$\mathrm{K}$ : persen kolonisasi

BKP : berat kering pucuk 
Tabel 2. Rekapitulasi hasil uji BNT untuk seluruh variabel penelitian penggunaan berbagai media tanam dan ektomikoriza untuk meningkatkan kolonisasi dan pertumbuhan damar mata kucing (S. Javanica)

\begin{tabular}{lccccccccc}
\hline Perlakuan & $\begin{array}{c}\boldsymbol{\Delta T} \\
(\mathbf{c m})\end{array}$ & $\begin{array}{c}\boldsymbol{\Delta D} \\
(\mathbf{m m})\end{array}$ & $\begin{array}{c}\boldsymbol{\Sigma} \mathbf{D} \\
(\mathbf{h e l a i})\end{array}$ & $\begin{array}{c}\mathbf{L D} \\
\left(\mathbf{c m}^{2}\right)\end{array}$ & $\begin{array}{c}\text { BKP } \\
(\mathbf{g})\end{array}$ & $\begin{array}{c}\text { BKA } \\
(\mathbf{g})\end{array}$ & $\begin{array}{c}\text { BKT } \\
(\mathbf{g})\end{array}$ & $\begin{array}{c}\text { PA } \\
(\mathbf{c m})\end{array}$ & $\begin{array}{c}\mathbf{K} \\
(\boldsymbol{\%})\end{array}$ \\
\hline P1 & $7,34 \mathrm{~b}$ & $1,67 \mathrm{a}$ & $7,33 \mathrm{a}$ & $32,41 \mathrm{a}$ & $0,28 \mathrm{a}$ & $1,12 \mathrm{~b}$ & $3,02 \mathrm{~b}$ & $12,97 \mathrm{~b}$ & $53,79 \mathrm{~b}$ \\
P2 & $8,27 \mathrm{a}$ & $1,46 \mathrm{a}$ & $7,67 \mathrm{a}$ & $34,51 \mathrm{a}$ & $0,32 \mathrm{a}$ & $1,45 \mathrm{a}$ & $3,54 \mathrm{a}$ & $15,99 \mathrm{a}$ & $85,29 \mathrm{a}$ \\
P3 & $1,13 \mathrm{c}$ & $1,10 \mathrm{~b}$ & $3,33 \mathrm{~b}$ & $23,14 \mathrm{~b}$ & $-0,37 \mathrm{c}$ & $0,70 \mathrm{c}$ & $1,12 \mathrm{c}$ & $10,81 \mathrm{~b}$ & $19,32 \mathrm{c}$ \\
P4 & $1,19 \mathrm{c}$ & $0,83 \mathrm{~b}$ & $3,67 \mathrm{~b}$ & $22,50 \mathrm{~b}$ & $-0,24 \mathrm{~b}$ & $0,79 \mathrm{c}$ & $1,37 \mathrm{c}$ & $15,18 \mathrm{a}$ & $16,93 \mathrm{c}$ \\
\hline BNT 5\% & 0,81 & 0,29 & 1,09 & 6,43 & 0,09 & 0,18 & 0,45 & 2,19 & 10,19 \\
\hline
\end{tabular}

Keterangan:

P1 : tanah, P2: pasir, P3: arang sekam, P4: cocopeat

-Data BKP telah diolah menggunakan transformasi logaritma

-Nilai tengah pada setiap kolom yang diikuti oleh huruf yang sama tidak berpengaruh nyata pada taraf nyata $1 \%$

Rekapitulasi hasil uji BNT menyatakan bahwa media pasir berpengaruh paling baik pada variabel tinggi bibit, berat kering akar, berat kering total, panjang akar dan persen kolonisasi. Penggunaan media tanah memberikan hasil pertumbuhan yang baik namun persen kolonisasinya lebih rendah dibandingkan pasir. Sementara arang sekam dan cocopeat tampaknya merupakan media yang kurang menunjang pertumbuhan S. javanica dan kolonisasi ektomikoriza. Persen kolonisasi akar berektomikoriza untuk masing masing perlakuan disajikan pada Gambar 1.

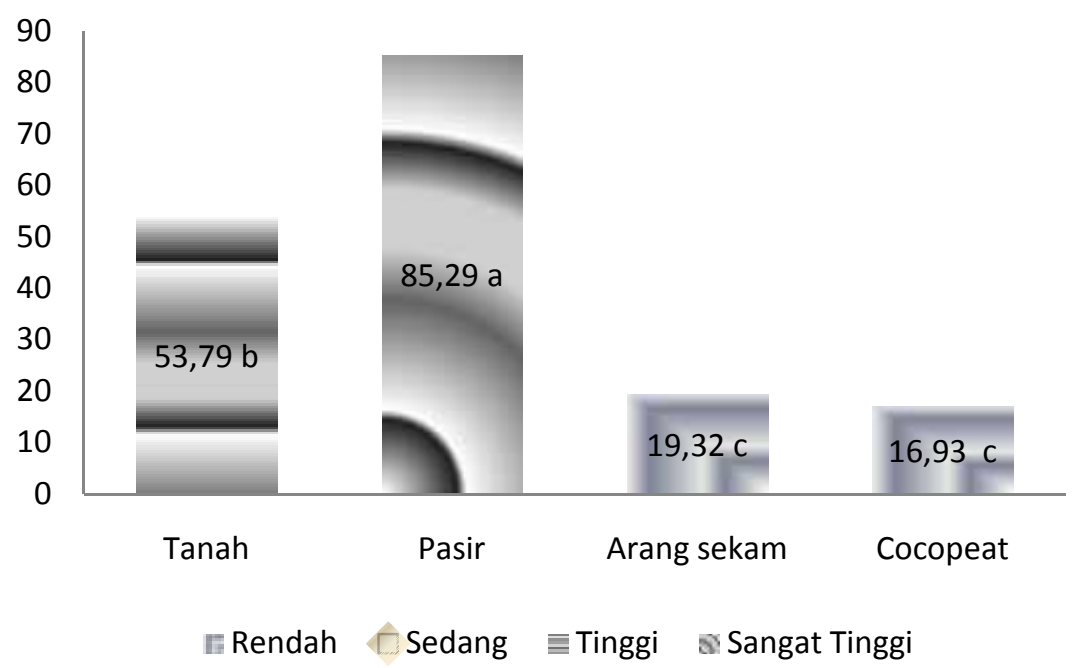

Gambar 1. Persen kolonisasi akar berektomikoriza pada S. javanica berumur 4 bulan setelah diinokulasi dengan S. columnare

\section{PEMBAHASAN}

Persen kolonisasi ektomikoriza dan pertumbuhan damar mata kucing dapat dipengaruhi oleh media tumbuh. Penggunaan media tanam yang berbeda dan pemberian ektomikoriza pada damar mata kucing menunjukkan hasil pertumbuhan dan persen kolonisasi yang berbeda pula. Hal ini terlihat dari variabel yang diamati meliputi tinggi tanaman, diameter tanaman, jumlah daun, luas daun, berat kering pucuk, berat kering akar, berat kering total, panjang akar dan persentase kolonisasi akar yang menunjukkan hasil berbeda nyata. 


\section{Pengaruh Penggunaan Berbagai Media Tanam dan Inokulasi Spora terhadap Persentase Kolonisasi Akar Berektomikoriza}

Jenis media tanam dapat mempengaruhi tingkat keberhasilan dan keefektifan infeksi mikoriza pada akar tanaman inang (Lugito, 2015). Media tanam yang digunakan pada penelitian ini yaitu media tanah, pasir, arang sekam dan cocopeat. Menurut beberapa peneliti penambahan arang sekam pada media tanam tanah berpotensi dalam meningkatkan kolonisasi ektomikoriza (Nurbaity dkk., 2009; Nurbaity dkk., 2011; Muryanto, 2012; Kartika dkk., 2014; Suswati dkk., 2015). Hal ini dikarenakan penambahan arang sekam dapat memperbaiki porositas dan aerasi tanah. Media arang sekam dalam penelitian ini tidak dilakukan pencampuran dengan media lain (murni) yang ternyata berpengaruh buruk bagi keberadaan koloni ektomikoriza. Hal ini diduga karena pada kondisi arang sekam murni porositas media semakin meningkat dan aerasi semakin buruk. Pendapat ini diperkuat oleh Prayudyaningsih (2012), yang menyatakan bahwa aerasi yang buruk dapat menghambat pertumbuhan mikoriza.

Persen kolonisasi yang rendah juga ditemukan pada penggunaan media cocopeat. Menurut Irawan dkk (2015), media cocopeat memiliki kemampuan mengikat dan menyimpan air yang sangat kuat sehingga lebih rentan mengalami penjenuhan air. Selain itu, Mulyawan dkk (2015) menyebutkan bahwa komposisi utama serbuk sabut kelapa (cocopeat) tersusun oleh lignin (41\%) dan selulosa (27\%). Menurut Hadi (2001), umumnya mikoriza tidak dapat menguraikan lignin dan hanya sedikit yang mampu menghasilkan enzim untuk menguraikan selulosa.

Penggunaan media pasir sebagai media tanam, dapat meningkatkan jumlah kolonisasi ektomikoriza. Berdasarkan kriteria jumlah kolonisasi, media pasir memperoleh kriteria sangat tinggi dengan perolehan sebesar 85,29\%. Keadaan ini sejalan dengan penelitian Darwo dan Sugiarti (2008) bahwa penambahan media pasir sebagai media tumbuh bibit tusam yang telah diinokulasikan dengan $S$. citrinum menghasilkan persen infeksi sebesar 77,60\%. Sama halnya dengan Sariasih (2014), yang menyatakan bahwa medium pasir gunung memberikan perolehan jumlah spora yang sangat baik.

Persen kolonisasi yang tinggi menunjukkan adanya simbiosis mutualisme yang baik antara mikoriza dengan akar tanaman sehingga variabel kolonisasi sangat berpengaruh terhadap variabel lainnya. Simbiosis ini memungkinkan akar memperluas daerah serapan hara yang secara tidak langsung akan meningkatkan kemampuan fotosintesis tanaman. Berdasarkan hasil analisis, persen kolonisasi yang tinggi berbanding lurus dengan luas permukaan daun. Semakin besar luas permukaan daun maka daerah untuk terjadinya fotosintesis akan semakin besar yang berpengaruh terhadap hasil fotosintesis yang akan digunakan untuk pertumbuhan dan perkembangan sel tanaman.

\section{Pengaruh Penggunaan Berbagai Media Tanam dan Inokulasi Spora terhadap Pertumbuhan Damar Mata Kucing}

Berdasarkan hasil analisis, jenis media tanam yang baik dalam meningkatkan pertumbuhan tanaman adalah media pasir. Tingginya respon pertumbuhan pada media pasir diduga karena media pasir memiliki aerasi yang baik sehingga memungkinkan terjadinya asosiasi antara $S$. javanica dengan $S$. columnare yang dibuktikan dengan jumlah kolonisasi akar yang lebih tinggi. Hal ini sejalan dengan Hadi (2001) yang menyatakan bahwa tingginya pertumbuhan bibit seiring dengan tingginya air dan unsur hara yang terserap oleh akar berektomikoriza. Selain itu, menurut Talanca (2010), mikoriza juga berperan dalam menstimulus pembentukan hormon-hormon pertumbuhan tanaman, seperti sitokinin dan auksin. Hormon sitokinin dan auksin ini berperan dalam pembelahan dan pemanjangan sel, sehingga menyebabkan peningkatan tinggi tanaman. 
Penggunaan media tanah yang telah diinokulasikan dengan $S$. columnare sebagai media pertumbuhan $S$. javanica menunjukkan hasil yang berbeda nyata dengan media pasir pada variabel pertambahan tinggi, panjang akar, berat kering akar dan berat kering total. Pada variabel pertambahan diameter, berat kering pucuk, jumlah daun dan luas daun menunjukkan hasil yang sama baiknya dengan penggunaan media pasir. Hasil ini sejalan dengan penelitian Irianto dkk. (2011), bahwa inokulasi pemberian mikoriza dapat meningkatkan pertumbuhan diameter dan biomassa bibit nyawai (Ficus variegata). Respon pertumbuhan S. javanica yang baik ini diduga karena keadaan lingkungan pada media tanah mampu menyokong pertumbuhan mikoriza yang nantinya akan membantu akar tanaman dalam menyerap unsur hara dan air yang dibutuhkan dalam pertumbuhan tanaman.

Muis dkk (2013), menyatakan bahwa tanaman yang diinokulasikan dengan mikoriza akan subur karena luas permukaan akar yang lebih besar untuk menyerap unsur hara dan air serta jumlah daun yang lebih banyak untuk melakukan fotosintesis. Pendapat ini berbeda dengan keadaan di lapangan, tidak semua tanaman yang diinokulasikan dengan mikoriza dapat tumbuh dengan baik. Pertumbuhan $S$. javanica yang diinokulasikan dengan $S$. columnare pada media arang sekam dan cocopeat lebih buruk dibandingkan dengan media pasir dan tanah.

Respon pertumbuhan yang rendah pada cocopeat kemungkinan disebabkan terjadinya persaingan nutrisi antara tanaman dengan mikroorganisme pada media. Menurut Prayudyaningsih (2012), pemilihan media bahan organik yang tidak tepat dapat menimbulkan masalah karena masih berlangsungnya proses dekomposisi oleh mikroorganisme sehingga nitrogen yang terkandung dalam media diambil oleh mikroorganisme untuk keperluan hidupnya dan menyebabkan semai kekurangan nitrogen. Pada media arang sekam dalam penelitian ini, respon pertumbuhan yang rendah diduga karena media arang sekam yang cenderung menyerap panas lebih banyak dibandingkan dengan media lain sehingga menyebabkan daun $S$. javanica banyak yang terbakar. Semakin sedikit daun yang dapat melakukan fotosintesis maka semakin sedikit hasil fotosintesis yang disuplai ke seluruh bagian tumbuhan. Hal ini sejalan dengan Susilawati (2007) yang menyatakan bahwa arang sekam dapat mengabsorbsi sinar matahari secara efektif sehingga dapat menaikkan suhu media.

\section{SIMPULAN DAN SARAN}

\section{Simpulan}

Jenis media tanam yang paling baik dalam meningkatkan kolonisasi ektomikoriza pada $S$. javanica adalah media pasir. Penggunaan media pasir dan tanah yang diberi $S$. columnare dapat meningkatkan pertumbuhan S. javanica.

\section{Saran}

Media arang sekam dan cocopeat sebagai media tanam lebih baik digunakan dalam bentuk pencampuran antar media. 


\section{DAFTAR PUSTAKA}

Brundrett, M., Bougher N., Dell B., Grove T., dan Malajczuk N. 1996. Working with Mycorrhiza in Forestry and Agriculture. Buku. Australian Centre for International Agricultural Research. Canberra. Hlm 83

Darwo dan Sugiarti. 2008. Pengaruh dosis spora cendawan Scleroderma citrinum Persoon dan komposisi media terhadap pertumbuhan tusam di persemaian. Jurnal Penelitian Hutan dan Konservasi Alam. 5(5): 461-472

Hadi, S. 2001. Patologi Hutan Perkembangannya di Indonesia. Buku. Fakultas Kehutanan Institut Pertanian Bogor. Bogor. Hlm 267

Irawan, A. dan Kafiar Y. 2015. Pemanfaatan cocopeat dan arang sekam padi sebagai media tanam cempaka wasian. Prosiding. Seminar Nasional Masyarakat Biodiversitas Indonesia. 4 Juli 2015. Hlm 806-807

Irianto, R., dan Effendi R. 2011. Pengaruh fungi mikoriza arbuskular terhadap pertumbuhan bibit nyawai. Prosiding. Seminar nasional mikoriza. Bandar Lampung. 20-21 Juli 2011. Hlm 85-89

Kartika, Y., Nurbaity A., Fitriatin B., dan Sofyan E. 2014. Efek sterilisasi dan komposisi media inokulan konsorsium mikoriza arbuskular dan mycorrhizal helper bacteria terhadap jumlah spora MA, populasi MHB, dan nisbah pupus akar sorgum. Agric Sci Jurnal. $1(4): 262-268$

Lugito. 2015. Kombinasi Vermikulit dan Pasir Sebagai Media Untuk Memproduksi Fungi Mikoriza Arbuskular Pada Tanaman Inang Jagung dan Kudzu. Skripsi. Universitas Lampung. Bandar Lampung.

Mansur, I. 2013. Teknik Silvikultur Untuk Reklamasi Lahan Bekas Tambang. Buku.SEAMEO BIOTRO. Bogor. Hlm 49

Mulyawan, M., Setyowati E., dan Widjaja A. 2015. Surfaktan sodium ligno sulfonat dari debu sabut kelapa. Jurnal Teknik ITS. 4(1):1-3

Muryanto. 2012. Uji Efektivitas dan Multiplikasi Spora CendawanMikoriza Arbuskular (CMA) Pada Berbagai Media Pembibitan Dalbergia latifolia. Tesis. Universitas Sebelas Maret. Surakarta. Hlm 48-50

Nurbaity, A., Hardiyantoro D., dan Mulyani O. 2009. Pemanfaatan bahan organik sebagai bahan pembawa inokulan fungi mikoriza arbuskula. Jurnal Biologi. 8(1) : 17- 11

Nurbaity, A., Setiawan A., dan Mulyani O. 2011. Efektivitas arang sekam sebagai bahan pembawa pupuk hayati mikoriza arbuskularpada produksi sorgum. Agrinimal, 1(1) 3-5

Prameswari, D. 2004. Aplikasi beberapa cendawan ektomikoriza untuk meningkatkan pertumbuhan semai Shorea selanica. J Hut Trop 1:13-18

Prayudyaningsih, R. 2012. Mikoriza dalam pengelolaan hama-penyakit terpadu di pesemaian. Info Teknis Eboni. 9(1):59-70 
Purwaningsih. 2004. REVIEW:Sebaran ekologi jenis-jenis dipterocarpaceae di Indonesia. Jurnal Biodiversitas. 5(5): 89-95

Sariasih, Y., Sutraswati M., dan Hartal. 2014. Respon pertumbuhan dan Hasil tanaman cabai terhadap aplikasi Fungi mikoriza arbuskular (FMA) berbagai media pasir. J.Agrotek.Trop. 3(1) 29-31

Santoso, E. 2007. Aplikasi mikoriza untuk meningkatkan kegiatan rehabilitasi hutan dan lahan terdegradasi. Prosiding Ekspose Hasil-Hasil Penelitian. Padang. Hlm 71-80

Susilawati, E. 2007. Pengaruh Komposisi Media terhadap Perkecambahan dan Pertumbuhan Tanaman Helichrysum bracteatum dan Zinnia elegans. Skripsi. Institut Pertanian Bogor. Bogor. Hlm 15-17

Suswati, Indrawati A., dan Putra D. 2015. Penapisan limbah pertanian (sabut kelapa dan arang sekam) dalam peningkatan ketahanan bibit pisang barangan bermikoriza terhadap blood diseae bacterium dan fusarium oxysporum. J HPT Tropika. 15(1) : 81-88

Talanca, H. 2010. Status Cendawan Mikoriza Vesikular Arbuskular pada tanaman. Prosiding. Pekan Serealia Nasional. Sulawesi Selatan. Hlm 356-357 